\title{
Range condition from an ecological perspective: Modifica- tions to recognize multiple use objectives
}

\author{
REX D. PIEPER AND RELDON F. BECK
}

\begin{abstract}
Two changes in traditional range condition analyses are recommended: (1) to replace the terms excellent, good, fair, and poor with ecological equivalents of climax, late seral, mid-seral, and early seral in cases where this is practical; and (2) to develop relationships between products (e.g., livestock, wood products, water) or conditions (e.g., infiltration, site stability, erosion) and successional stage or state. Such information will allow the land manager to evaluate possible tradeofís between managing for a particular successional stage or state and particular goods or services.
\end{abstract}

Key Words: resource values, secondary succession, seral stages

Smith (1979) stated that the concept of range condition is "perhaps the most important one in range management." Yet much uncertainty and controversy surrounds not only the meaning of the concept, but also the methods of its determination and application. Aside from short-term considerations of current forage conditions on a range (Gray 1975), range condition has usually referred to present vegetational composition or production, in relation to the potential for the site (Tueller 1973, Stoddart et al. 1975, Smith 1984).

Although several specific methods for range condition classification have been used (Pamo 1983, Smith 1984), these can be grouped into 2 general approaches: site potential approach based on primary productivity; and an ecological approach based on departures from climax (Hacker 1983, Pamo 1983, and Smith 1979). In either case, determining potential or climax conditions can be difficult.

In some situations the stated management objective is to improve range condition. However, the definition of what constitutes improvement is lacking. Are we trying to increase productivity of a species or to increase soil water infiltration? Does improvement reduce shrubby cover? Recognizing the relationship between specific products or uses and successional stage may help managers focus their goals and objectives.

The objective of this paper is to describe an approach to range condition classification which combines some features of both a site potential and ecological approach. Our approach embodies some of the suggestions provided by Smith $(1979,1984)$.

\section{General Approach}

The quantitative climax approach to range condition classification is tied closely to the concept of secondary succession (Dyksterhuis 1949, 1958). Condition classes (excellent, good, fair, and poor) correspond to degrees of deterioration or departures from a perceived climax (Thomas and Ronnigan 1970). Originally, the concept of condition probably did not refer to any specific land use, although the terms "decreaser" and "increaser" referred to reaction of species to grazing. However, land managers are interested in other uses and responses of range sites or habitat types (Smith 1979). In addition, the terms excellent, good, fair, and poor may not portray the intended connotation for the land manager

Authors are professors, Department of Animal and Range Sciences, New Mexico State Univ., Journal Article 1387, New Mexico Agr. Exp. Sta., Las Cruces 88003.

Manuscript accepted 13 April 1990. (i.e., wildlife habitat, water, primary production). Several uses may be maximized at some stages below climax. Smith (1979) recommended dropping these descriptive terms and using a numerical rating to reflect site condition. The foundation of range management is applied ecology and the concept of range condition (and trend) should remain grounded in the perspective of succession to the extent possible (Smith 1979). We recommend using ecological terms climax, late seral, mid-seral, and early seral stages to replace excellent, good, fair, and poor stages. These terms indicate only ecological condition, not suitability for a particular use. Of course, such terms relate to stages along a continuum from climax to early seral stages. Distinguishing between stages is always somewhat arbitrary, although many techniques are available.

\section{An Example}

Since range condition is based on or reflects succession, the next step in our approach is to consider products or conditions of land use as variables which depend (in part) on successional stage. Such an approach was used by Brown et al. (1974) to determine multipleuse values following control of ponderosa pine (Pinus ponderosa Laws) forests in northern Arizona.

A specific example comes from the sandy upland range site in southern desert rangeland, southern New Mexico. Four range condition classes have been described by Gay (1965) as follows:

Excellent condition-A pure stand of black grama (Bouteloua eriopoda [Torr.] Torr.) with occasional yuccas (Yucca spp.) present.

Good condition-Mostly black grama with some mesa and sand dropseed (Sporobolus flexuosus [Thurb.] Rydb. and S. cryptandrus [Torr.] Gray), snakeweed (Gutierrezia sarothrae [Pursh] Britt. \& Rushby), and numerous annuals.

Fair condition-Some black grama, mostly mesa dropseed; mesquite (Prosopis glandulosa [Torr.]) and yucca evident. Much of site production due to annual grasses and forbs.

Poor condition-Mesquite, yucca and snakeweed are dominant. A few scattered mesa dropseed plants are present. Extreme erosion has exposed the caliche layer. No desirable grasses present.

These desert grassland ranges are used for cattle grazing, but successional status also influences many other components of these ecosystems (Pieper et al. 1983). The relationship between some of these components and successional stages, assuming a complete correspondence between range condition classes and successional stage, is shown in Figure 1. These relationships were based on the current information available, but are used only for illustrative purposes. In some cases, it might be desirable to recognize a fifth category below the early seral stage, which could be called the pioneer stage.

Data on forage biomass came from studies on the Jornada Experimental Range (Pieper and Herbel 1982, Paulsen and Ares 1962), the New Mexico State University College Range (Pamo 1983), and other locations in southern New Mexico (Beck and Tober 1985). Data on pronghorn density came from Howard et al. (1973), small mammals from Wood $(1965,1969)$, birds from Raitt and Pimm (1976), and erosion from Gould 1982).

Cattle prefer black grama during the winter dormant period and 

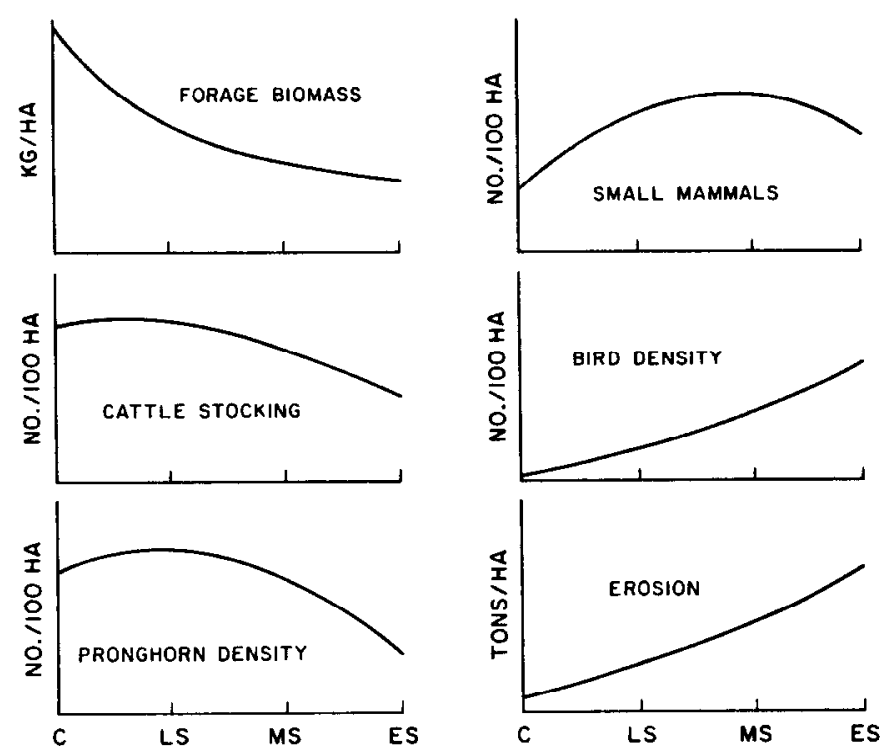

Fig. 1. Changes in ecosystem attributes or products as a function of successional stage for a sandy upland range site in southern New Mexico. C = Climax; HS = High Seral; MS = Mid-Seral; LS = Low Seral.

mesa dropseed during the summer (Rosiere et al. 1975, GonzalezRodriquez et al. 1978, Hakkila et al. 1987). In addition, earlier seral stages may provide more forbs to improve conditions for cattle grazing (Pieper and Beck 1980).

Figure 1 suggests that a mid-to-late successional stage may be the management goal when objectives are to maximize cattle grazing and pronghorn density. Although small mammal populations and upland bird densities are less than optimum at this stage, soil erosion is minimal, suggesting some degree of site stability. Such tradeoffs between products and/or conditions are necessarily contingent upon management goals.

Many ranges in southern New Mexico are subject to brush encroachment and eventual domination. In these cases, it appears that some "threshold" has been exceeded and the successional sequence outlined here no longer applies (Friedel 1988, Laycock 1989).

\section{Discussion}

Our approach eliminates the unfortunate connotation attached to the terms excellent, good, etc. used to describe range condition today. It also incorporates positive aspects of an ecological approach. One of the main benefits of an ecological approach is that the successional scheme provides a point of reference (successional stage) which the site-potential approach lacks. In the example presented, a mid-to-late stage may be the management objective to maximize cattle grazing and pronghorn density, with the manager recognizing that other products will be less than potential for the site. If site stability is a major object of the manager (Smith 1979), perhaps other measures of stability are needed in addition to protection from wind erosion.

Most management decisions involve tradeoffs of one kind or another. However, with this information a manager is in a position to know what the tradeoffs are. Others have also recommended using resource values in range condition evaluation (Anderson 1986, Floyd and Frost 1987, Hann 1986, Kindschy 1986, Lauenroth 1985, RISC 1983; and Wagner 1986). There appears to be a near consensus that range condition evaluation is moving away from a single criterion to include many factors.
This approach does not answer all problems associated with the ecological model: the problem of differentiating spatial and temporal variation remains. Recent publications have stressed the need for modifications in the traditional approaches to successional dynamics (Smith 1989). Peet and Christensen (1980) have outlined 3 general models to describe secondary succession: (1) Succession as a gradient in time; (2) Succession resulting from differential mortality of component species; and (3) Succession as a stochastic process. Each of these approaches serves a useful purpose in improving our understanding of successional processes. The procedure outlined in this paper depends somewhat on the degree of predictability of the succession-to-climax theory. Situations whereby several seral stages converge to a common climax (Huschle and Hironaka 1980) or where wide variation in the climax is possible (Heady 1973, Horn 1974) would render the approach more difficult to apply. Ellis and Swift (1988) and Westoby et al. (1989) have discussed grazing ecosystems not in equilibrium and unstable. Westoby et al. (1989) described several state and transition situations which follow an erratic path. Reaction of various herbivores, erosion, recreation potential, aesthetics and so on would have to be determined for each of these states for management decisions.

There are cases where successional patterns appear to be rather predictable. For example, several authors have described secondary succession in pinyon-juniper woodlands following disturbance (Arnold et al. 1964, Barney and Frischknecht 1974, Erdman 1976, and Schott and Pieper 1987). These pathways appear to be sufficiently similar to assign successional stages. In these cases livestock forage would be greatest when tree density was lowest (Pieper 1983). Other areas where the approach might have utility would be in the Great Plains (Dodds and Goetz 1981).

This approach would not answer the problem of introduced species such as cheatgrass (Bromus tectorum L.) in the Intermountain area, or Lehman lovegrass (Eragrostis lehmanniana Nees.) in Arizona. However, it should be possible to develop successional schemes with these species considered part of the natural flora (e.g., Hironaka and Tisdale 1963).

This approach also provides a framework to determine kinds of information needed for management decisions. Some of this information can only be derived by research, but other information might be obtained by experience. In any case, range condition evaluation is sufficiently important to require more of our attention. It is our intention to continue the discussion of this important topic.

\section{Literature Cited}

Anderson, E.W.1986. Rating ecological status and resource values. Rangelands 8:161-164.

Arnold, J.F., D.A. Jameson, and E.H. Reid. 1964. The pinyon-juniper type of Arizona: effects of grazing, fire, and tree control. USDA Prod. Res. Rep. 84.

Barney, M.A., and N.C. Frischknecht. 1974. Vegetation change following fire in the pinyon-juniper type of west-central Utah. J. Range Manage. 27:91-96.

Beck, R.F., and D.A. Tober. 1985. Vegetational changes on creosotebush sites after removal of shrubs, cattle and rabbits. New Mex. Agr. Exp. Sta. Bull. 717.

Brown, H.E., M.B. Baker, Jr., J.L. Rogers, W.P. Clary, J.L. Kouner, F.R. Larson, C.C. Avery, and R.E. Campbell. 1974. Opportunities for increasing water yields and other multiple use values on ponderosa pine forest lands. Forest Serv. Res. Paper RM-219.

Dodds, D.L., and H. Goetz. 1981. Range condition-a guide to management. North Dakota State Univ., Coop. Ext. R-751.

Dyksterhuis, E.J. 1949. Condition and management of rangeland based on quantitative ecology. J. Range Manage. 2:104-115.

Dyksterhuis, E.J. 1958. Ecological principle in range evaluation. Bot. Rev. 24:253-272. 
Ellis, J.E., and D.M. Swift. 1988. Stability of African pastoral ecosystems: alternate paradigms and implications for development. J. Range Manage. 41:450-459.

Erdman, J.A. 1970. Pinyon-juniper succession after natural fires on residual soils of Mesa Verde, Colorado. Brigham Young Univ. Sci. Bull. Biol. Ser. 11:26 p.

Floyd, D., and B. Frost. 1987. Measuring management objectives with condition classes: time for a change. Rangelands 9:161-162.

Freidel, M.H. 1988. Range condition and the concept of thresholds. In: Abstracts 3rd Internat. Rangeland Congr. Vol. I. New Delhi, India.

Gay, C. 1965. Range management-how and why. New Mexico State Univ., Coop. Ext. Ser. Circ. 376.

Gonzalez-Rodriquez, J.K., R.D. Pieper, and G.S. Smith. 1978. Botanical composition of cattle diets on desert grassland range. New Mexico State Univ. Agr. Exp. Sta. Res. Rep. 363.

Gray, J.R. 1975. The pasture and range feed condition report. Rangeman's J. 2:81-82.

Hakkila, M.D., J.L. Holechek, J.D. Wallace, D.M. Anderson, and M. Cardenas. 1987. Diet and forage intake of cattle on desert grassland. J. Range Manage. 40:339-342.

Hann, W.J. 1986. Evaluation of resource values in the northern region of the Forest Service. Rangelands 8:159-161.

Heady, H.F. 1973. Structure and function of climax. In: Hyder, D.N.(Ed.) Proc. Third Workshop of the U.S./Australia Rangelands Panel. Soc. Range Manage., Denver, Colo.

Hironaka, M., and E.W. Tisdale. 1963. Secondary succession in annual vegetation in southern Idaho. Ecology 44:810-812.

Hom, H.S. 1974. The ecology of secondary succession. Ann. Rev. Ecol. Sys. 5:25-37.

Howard, V.W., Jr., C.T. Engelking, E.D. Glidewell, and J.E. Wood. 1973. Factors restricting pronghorn increase on the Jornada Experimental Range. New Mexico Agr. Exp. Sta. Res. Rep. 245.

Huschle, G., and M. Hironaka. 1980. Classification and ordination of plant communities. J. Range Manage. 33:179-182.

Kindschy, R.R. 1986. Rangeland vegetative succession-Implications to wildlife. Rangelands 8:157-159.

Laurenroth, W.K. 1985. New directions for rangeland condition analysis. Proc. 38th Annu. Mtg., Soc. Range Manage., Denver, Colo. (selected papers). pp. 101-106.

Laycock, W.A. 1989. Secondary succession and range condition criteria: Introduction to the problem. In: Lauenroth, W.K. and W.A. Laycock (Eds.). Secondary succession and evaluation of rangeland condition. Westview Press, Boulder.

Pamo, E.T. 1983. Mathematical approach to range condition in comparison to the SCS method. Ph.D. Diss. New Mexico State Univ., Las Cruces.
Paulsen, H.A., and F.N. Ares. Grazing values and management of black grama and tobosa grasslands and associated shrub ranges of the southwest. USDA Tech. Bull. 1270.

Peet, R.K., and N.L. Christensen. 1980. Succession: a population process. Vegetatio 43:131-140.

Pieper, R.D., and R.F. Beck. 1980. Importance of forbs on southwestern ranges. Rangelands 1:35-36.

Pieper, R.D., and C.H. Herbel. 1982. Herbage dynamics and primary productivity of a desert grassland ecosystem. New Mexico State Univ. Agr. Exp. Sta. Bull. 695.

Pieper, R.D., J.C. Anway, M.A. Ellstrom, C.H. Herbel, R.L. Packard, S.L. Pimm, R.J. Raitt, E.E. Staffeldt, and J.G. Watts. 1983. Structure and function of North American desert ecosystems. New Mexico State Univ. Agr. Exp. Sta. Special Rep. 39.

Raitt, R.J., and S.L. Pimm. 1976. Dynamics of bird communities in the Chihuahuan Desert, New Mexico. Condor 78:427-442.

Range Inventory Standardization Committee. 1983. Guidelines and terminology for range inventories and monitoring. Soc. Range Manage., Denver.

Rosiere, R.E., R.F. Beck, and J.D. Wallace. 1975. Cattle diets on semidesert grassland: botanical composition. J. Range Manage. 28:94-96.

Schott, M.R., and R.D. Pieper. 1987. Succession of pinyon-juniper communities after mechanical disturbance in southcentral New Mexico. J. Range Manage. 40:88-94.

Smith, E.L. 1979. Evaluation of the range condition concept. Rangelands 1:52-54.

Smith, E.L. 1984. Use of inventory and monitoring data for range management purposes. $l n$ : Developing strategies for rangeland management. Westview Press, Boulder.

Smith, E.L. 1988. Successional concepts in relation to range condition assessment. In: Tueller, P.T. (Ed.). Vegetation science applications for rangeland analysis and management. Kluwer Academic Pub. Boston.

Stoddart, L.A., A.D. Smith, and T.W. Box. 1975. Range Management. McGraw-Hill Book Co., New York.

Tueller, P.T. 1973. Secondary succession, disclimax, and range condition standards in desert shrub vegetation. In: Hyder, D.N. (Ed.). Proc. Third Workshop of U.S./Australia Rangelands Panel-Tucson, Ariz. Soc. Range Manage., Denver, Colo.

Westoby, M., B. Walker, and I. Noy-Meir. 1989. Opportunistic management for rangelands not at equilibrium. J. Range Manage. 42:266-274.

Wood, J.E. 1965. Response of rodent populations to controls. J. Wildl. Manage. 29:425-437.

Wood, J.E. 1969. Rodent populations and their impact on desert rangelands. New Mexico State Univ. Agr. Exp. Sta. Bull. 555. 